\title{
LVIII. Astronomical observations 1827
}

\section{Lieut. George Beaufoy R. N.}

To cite this article: Lieut. George Beaufoy R. N. (1827) LVIII. Astronomical observations 1827, Philosophical Magazine Series 2, 1:4, 290-290, DOI: 10.1080/14786442708675587

To link to this article: http://dx.doi.org/10.1080/14786442708675587

$$
\text { 曲 Published online: } 10 \text { Jul } 2009 .
$$

Submit your article to this journal 5

Q View related articles ¿ 
290 Lieut. G. Beaufoy's Astronomical Observations 1827.

appearance through every modification of woody clay and gravel, peat and beds of forest trees, that it is otten difficult to determine whether their real position be above or beneath the crag. Certainly, near Cromer, the trees are a few feet above the crag stratum, and are about the level of high water.

Perhaps the most probable conclusions, to be derived from a consideration of all these circumstances, are these :-

That after the formation of the chalk, the waters deposited the marine exuviæ, and gave existence, during the long period in which they occupied that portion of the former surface, to those remarkable accumulations of crag shells which we now witness.

That the trees and vegetables covered various parts of the surface of this new formation after it had become consolidated.

That in this state, these woodland tracts afforded shelter and support to certain animals, whose traces we find both amongst the vegetable deposits and in the drifted heaps containing marine substances.

Finally: All were buried in one common catasstrophe. The same eruption of the waters that overthrew the pines and forest trees, destroyed the herbivorous animals, and buried the crag shells, beneath the ruins of more ancient strata.

[To be continued.]

LVIII. Astronomical Observations 1827. By Lieut. GEorge Beaufoy, $R$. $N$.

Bushey Heath, near Stanmore.

ATITUDE $51^{\circ} 37^{\prime} 44^{\prime \prime} \cdot 3$ North. Longitude west in time $1^{\prime} 20^{\prime \prime} \cdot 93$.

Observed transits of the moon, and moon-culminating stars over the middle of the transit instrument in sidereal time.

1827. Stars. Transits.

Feb. 13. $62 \mathrm{~g}$ Leonis . . . . . $10^{\circ} 54^{\prime} 47^{\prime \prime} \cdot 64$

13. 69 Leonis . . . . . . $1104 \quad 56 \cdot 62$

13. Moon (18) ....... $11 \quad 2041 \cdot 16$

Eclipses of Jupiter's Satellites.

Feb. 17th. Emersion of $\left\{12^{\mathrm{h}} 45^{\mathrm{m}} 41^{\mathrm{s}} \cdot 06\right.$ M.T. at Bushey.

Jupiter's 3d satellite $\left\{\begin{array}{llll}12 & 4.7 & 01 & 99 \\ \text { M.T. at Greenwich. }\end{array}\right.$

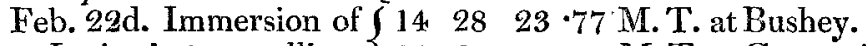

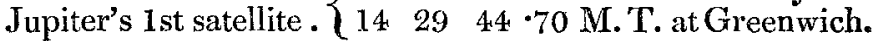

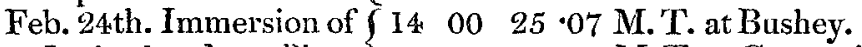

Jupiter's 3d satellite. $\left\{\begin{array}{llll}14 & 01 & 46 \cdot 00 & \text { M.T. at Greenwich. }\end{array}\right.$

Fej. 24th. Emersion of $\left\{\begin{array}{llll}16 & 42 & 21 \cdot 08 & \text { M.T. T. at Bushey. }\end{array}\right.$

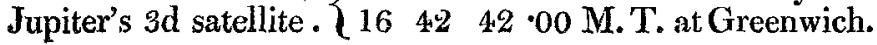

